\title{
Impact of corruption on the economic and environmental security of the state
}

\author{
Lyudmila Kopteva ${ }^{1, *}$, Arthur Budagov ${ }^{2}$, and Anna Trushevskaya ${ }^{2}$ \\ ${ }^{1}$ Saint-Petersburg State University of Aerospace Instrumentation,190000, 67, Bolshaya Morskaia str., \\ Saint-Petersburg, Russia, \\ ${ }^{2}$ North-West Institute of Management of the Presidential Academy of National Economy and Public \\ Administration (NWIM RANEPA), 199178, Sredny prospect VO, 57/43, Saint Petersburg, Russia
}

\begin{abstract}
Corrupt activities in the Russian Federation have reached the point where national security is under threat. Corruption creates obstacles to the economic growth of the state, slows down various transformations not only in the economic, but also in the social sphere of society, worsens the standard of living in the Russian Federation, undermines public confidence in public authorities, and reduces authority in the eyes of other countries. Theoretically, broad corrupt activities are able to destroy the norms, constitutional foundations that have developed in society and neutralize the operation of any legal system. One should not lose sight of the fact that corruption activity, due to its illegal origin, intersects with other variants of socially destructive phenomena, such as sanctioned crime, shadow economy and terrorist attacks. As a result, it can be said that corruption is a combination of various factors, a continuously growing system that threatens the state and financial security of the country, and is not an independent unit, which is an exceptional precedent of bribery of a certain person among civil servants.
\end{abstract}

\section{Introduction}

Nowadays, corruption, which has engulfed all spheres of life, has become a familiar, commonplace phenomenon. Small, medium, large private businesses, as well as state enterprises are interested in reducing the level of corruption.

As the President of the Russian Federation noted, "citizens have united around patriotic values not because they are happy with everything, that everything suits them. No, there are enough difficulties and problems now. But there is an understanding of their reasons, and most importantly - the confidence that together we will surely overcome them. Willingness to work for Russia, heartfelt, sincere concern for it - that is what lies at the heart of this union".

At this stage of the economic development of the Russian Federation, corruption in business, as well as in regional and federal government bodies, causes almost irreparable harm. It is worth taking into account the fact that there are much more unsolved corruption crimes, which means that it is impossible to realistically assess the scale of the damage

* Corresponding author: lusis63@mail.ru 
done. But even based on the obtained figures, it can be said that corruption has a negative impact on the overall development of the country, on its standard of living and, accordingly, on ensuring its economic security.

The purpose of the study is to consider the influence of the corruption component on the economic security of the state.

\section{Materials and methods}

In the process of considering the research topic, a number of scientific research methods were used, such as: general logical and theoretical methods. At the same time, the study is associated with sensory cognition of the problem under consideration.

The methodological basis of the study was made up of graphical, logical, informational analysis. The theoretical and empirical approaches to the consideration of the problem under study are used.

The issues of corruption and its impact on the economic security of the country were reflected in the works of the following Russian scientists: A.I. Altukhov, A.N. Semin, P. A Kabanova, V. S. Komissarova, I. G. Ushachev, N.V. Maltsev, A.V. Kurdyumov, A.G. Khabibullina and others.

Foreign authors also focus on the problems of combating corruption: S. Rose-Ackerman [1], R. Di Tela [2], A. Eids [2,3], De Melo, Martha [4]; Cevdet Denizer [4]; Alan Gelb [4]; Stoyan Tenev [4] and others.

\section{Research results}

The concept of "corruption" was formulated at the 34th session of the UN General Assembly on December 17, 1979 and was defined as "the performance by an official of any action (inaction) in the sphere of official powers for remuneration in any form in the interests of the one who gives such remuneration, with or without violation of job descriptions" [5].

Corruption is a very multifaceted concept. But at the same time, in a general concept, corruption implies, first of all, the abuse of official duties, powers, positions held in order to obtain their own benefit.

According to Federal Law No. 273 "On Combating Corruption", corruption is: "abuse of official duties, giving and receiving a bribe, abuse of authority, commercial bribery or other illegal use by an individual of his official position contrary to the legitimate interests of society and the state in order to obtain benefits in the form of money, valuables, other property or services of a property nature, other property rights for oneself or for third parties, or illegal provision of such benefits to the specified person by other individuals" $[6]$.

In a civilized state, the concept of corruption refers to a criminal offense. However, this form of responsibility has not yet eradicated this phenomenon, which has a variety of causes, forms and varieties.

Corruption as a phenomenon has the main features (Fig. 1): 


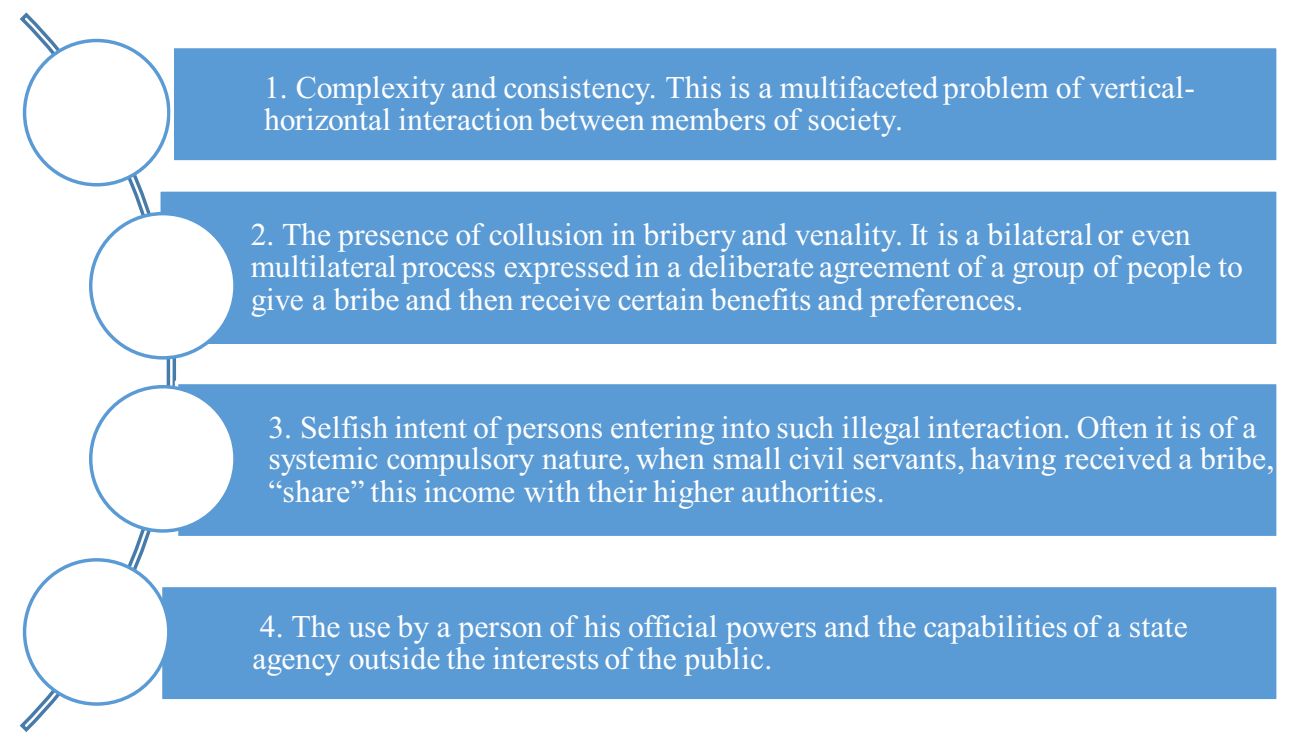

Fig. 1. The main signs of corruption.

Considering the reasons for corruption, which is why commercial bribery occurs in different states, it is rather difficult to come to a common opinion. Research shows a whole range of such problems (Fig. 2):

\section{CAUSES OF CORRUPTION}

\begin{tabular}{|c|c|c|c|c|}
\hline $\begin{array}{l}\text { 1. Personal greed, } \\
\text { low levels of } \\
\text { ethical } \\
\text { responsibility, and } \\
\text { lack of a sense of } \\
\text { duty and } \\
\text { community } \\
\text { service. }\end{array}$ & $\begin{array}{l}\text { 2. Bribery of an } \\
\text { official may arise } \\
\text { due to low wages } \\
\text { and lack of } \\
\text { opportunities for } \\
\text { self-realization in } \\
\text { the department. }\end{array}$ & $\begin{array}{l}\text { 3. Bribery also } \\
\text { arises due to the } \\
\text { absence of a } \\
\text { system of quick } \\
\text { and severe } \\
\text { punishments, } \\
\text { public censure } \\
\text { and endowing } \\
\text { such a person } \\
\text { with a "bad" } \\
\text { reputation. }\end{array}$ & $\begin{array}{l}\text { 4. In countries } \\
\text { where there is no } \\
\text { separate body } \\
\text { with broad powers } \\
\text { to combat } \\
\text { corruption and a } \\
\text { system of } \\
\text { independent } \\
\text { courts is } \\
\text { underdeveloped, } \\
\text { illegal activities } \\
\text { among officials is } \\
\text { booming. }\end{array}$ & $\begin{array}{l}\text { 5. Officials can } \\
\text { engage in fraud } \\
\text { also because the } \\
\text { state has not } \\
\text { developed a } \\
\text { unified reporting } \\
\text { system and } \\
\text { transparent access } \\
\text { to information on } \\
\text { the activities of a } \\
\text { state body. }\end{array}$ \\
\hline
\end{tabular}

Fig. 2. The main causes of corruption [7].

In a civilized state, the concept of corruption refers to a criminal offense. However, this form of responsibility has not yet eradicated this phenomenon, which has a variety of causes, forms and varieties (Fig. 3). 


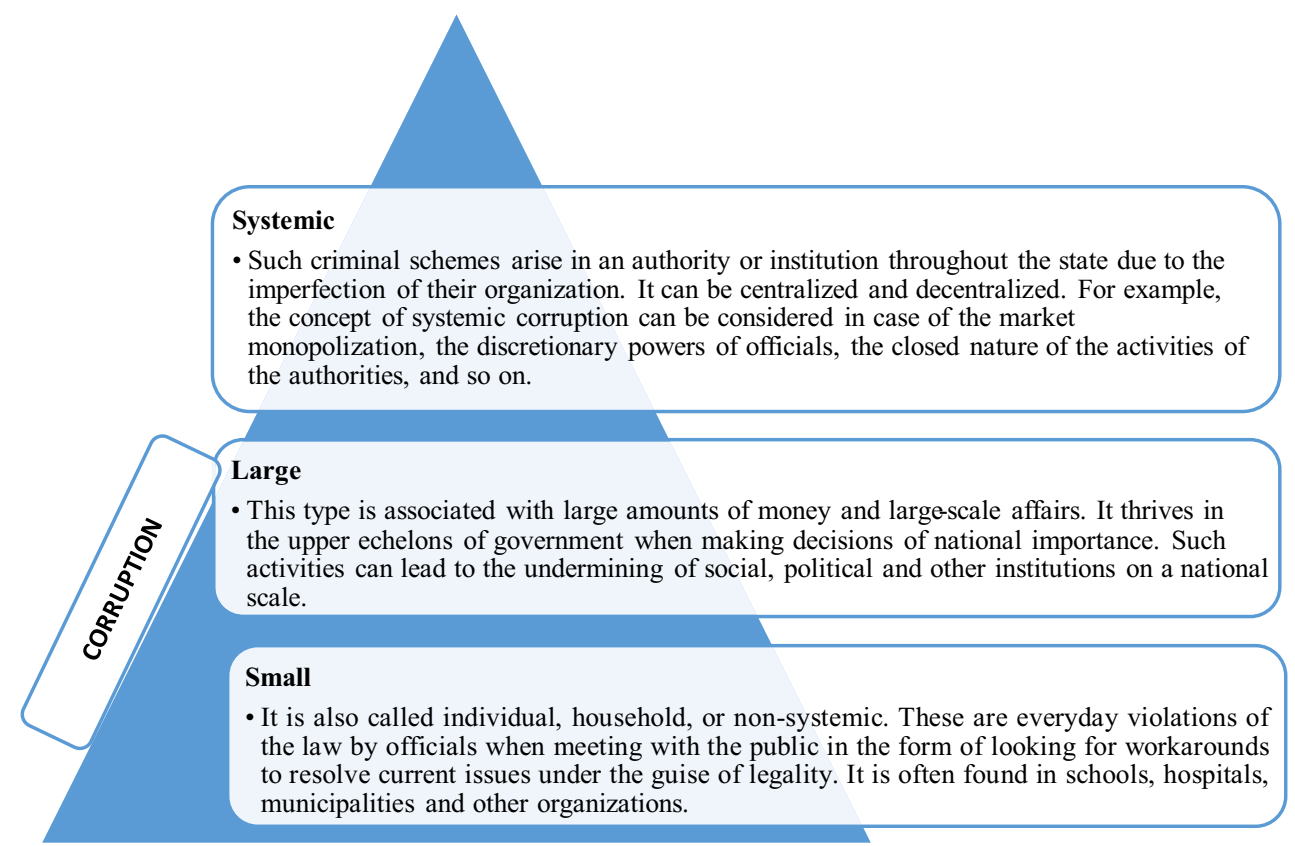

Fig. 3. Forms of corruption manifestation.

The main novelty of the Russian anti-corruption legislation in the past year was the introduction of the obligation of civil servants to declare digital financial instruments and digital currency: for example, from January 1 to June 30, 2021, persons entering the civil service, as well as employees moving to positions included in the list, will be required to submit a notification about their digital financial assets, digital currency, digital rights and utilitarian digital rights, and from July 2021, such information will be included in certificates of income, expenses, property and property obligations [8].

In addition, on December 29, the Ministry of Labor of Russia published an updated version of the Methodological Recommendations for the presentation of information on income and expenses for use during the 2021 declaration campaign.

Sixteen percent of economic crimes (or every sixth one) registered in Russia are business crimes. This is evidenced by the data of legal statistics, which was cited by TASS in the Prosecutor General's Office, responding to the agency's request [9].

According to statistics, the largest number of crimes falls on articles on tax crimes (Articles 198-199.2 of the Criminal Code of the Russian Federation), which is $79.5 \%$ of all detected crimes (2,045 per year). The article on misappropriation or embezzlement (Article 160 of the Criminal Code of the Russian Federation) takes the following position - 691 crimes incriminated to business entities, illegal use of trademarks (Article 180 of the Criminal Code of the Russian Federation) - 277 crimes, and the fourth position is taken by an article for violation of currency legislation (Article. 193, 193.1 of the Criminal Code of the Russian Federation) - 259 crimes [10].

Viktor Baldin, Head of the Office for Supervision over the Implementation of AntiCorruption Legislation of the Prosecutor General's Office of the Russian Federation, said: "The damage from corruption crimes in Russia in criminal cases initiated in 2020 amounted to more than 63 billion rubles".

If we estimate this amount, 63 billion rubles of damage from corruption [10], then this is: 
- slightly less than the revenues of the consolidated budget of the Penza region - for 2020 they amounted to 63.58 billion rubles.

- the amount of taxes collected in Naberezhnye Chelny for the year - in 2020, the budgets of all levels received 13\% more taxes than in 2019: 62.7 billion rubles.

- 21 times more than the largest (officially revealed) bribe in the history of Russia - it is 3 billion rubles. State Duma deputy Vadim Belousov is accused of receiving it. According to the investigation, he received such a sum for lobbying the interests of a firm from the Chelyabinsk region when concluding contracts for the construction and repair of roads in this region.

- almost half of this amount is made up of debts on fines that were imposed on convicted persons for corruption. At the end of 2020, the amount owed in fines imposed on those convicted of corruption in Russia exceeded 31 billion rubles, the average fine being 5 million rubles.

- $2.9 \%$ of the total budget of national projects in Russia in 2020, which amounted to 2.2 trillion rubles.

- $0.06 \%$ of Russia's GDP. At the same time, the IMF previously estimated that corruption in the whole world damages $1.5-2 \%$ of global GDP.

The amount of the established material damage caused by corrupt officials decreased compared to the same period in 2019 by $23.7 \%$ (from 38.4 billion to 29.3 billion rubles). At the same time, it was already possible to compensate for the damage by almost $60 \%$ - only money and valuables were seized for 2 billion rubles, which is three times higher than last year's figure.

The value of the seized property decreased from 14.1 billion to 13.6 billion rubles (by $3.4 \%$ ), while the amount of money, the value of the seized property and valuables, on the contrary, increased by more than $190 \%$ (from 693.4 million to 2 billion rubles).

The amount of voluntarily repaid damage was reduced by half - from 2.5 billion rubles (in the first half of 2019) to 1.2 billion rubles. Taking into account the damage voluntarily repaid by the criminals at the pre-trial stage, as well as the seized and distrained property, it was possible to take measures to ensure compensation for about $57.7 \%$ of the damage caused (in the first half of $2019-45 \%$ ).

If we consider corruption as the main factor of Russia's non-competitiveness, then according to the World Economic Forum in the Global Competitiveness Ranking 20172018, corruption affects:

- $\quad$ tax rates;

- $\quad$ formation of the state budget;

- $\quad$ access to finance;

- inflation;

- tax administration;

The consequences of the negative impact of corruption are such manifestations as:

- $\quad$ inadequate training of personnel;

- $\quad$ ineffective bureaucracy;

- $\quad$ low workforce ethics;

- $\quad$ inadequate infrastructure;

- $\quad$ instability of power;

- $\quad$ insufficient ability to innovate;

- $\quad$ currency regulation;

- $\quad$ restrictive labor legislation;

- crime;

- $\quad$ poor health of the population. 
In the fight to neutralize threats from corruption, the areas of countering business corruption as a threat to economic security in Russia have become a priotity, where the state has been strengthening control over the circulation of cash since January 2021. The main goal of the new measures is to bring unrecorded income out of the shadows. Strengthening of control is aimed at identifying the shadow income of individuals. For legal entities, operations have been controlled for a long time. Banking operations worth over 600 thousand rubles, postal orders, bets and refunds from mobile operators are targeted.

From January 2021, The Federal Financial Monitoring Service of the Russian Federation is expanding the list of controlled transactions. All events are carried out automatically without the participation of an individual. Banks, Russian Post and mobile operators will transmit information on financial monitoring. In this case, an individual will not be notified, but will find out about the activities being carried out if he receives a request to provide documents and explanations.

\section{Foreign experience}

In foreign countries, despite the pandemic, a number of important steps have been taken to prevent corruption in the public sector over the past year.

At the beginning of the year in France, the rules for part-time work and the procedure for regulating the "revolving door" were updated; documents clarifying the application of such restrictions were adopted in Thailand [11].

Abkhazia introduced the obligation to declare income and assets, Malaysia - the need to publish declarations of members of Parliament in the public domain.

Kazakhstan has established a complete ban on the receipt of gifts by government officials, provisions have been introduced in the legislation of Ukraine and Brazil to protect applicants, and in Mexico and Armenia, the possibility of confiscating illegally acquired property has been introduced.

In addition, the Vatican passed a regulation establishing measures to prevent corruption in public procurement.

Several countries of the Balkan Peninsula significantly transformed their anti-corruption legislation at once: a new anti-corruption law came into force in Serbia, in Slovenia, the working procedure and powers of the Commission for the Prevention of Corruption, the specifics of receiving gifts and some other provisions of anti-corruption legislation were clarified, and in Croatia, a guide was issued on the regulation of conflicts of interest.

In a number of countries, changes were made to the procedure for the application of penalties for corruption crimes: for example, in Indonesia, a unified algorithm for determining the appropriate punishment depending on the objective sides of the crime appeared; in Colombia, those sentenced to imprisonment were prohibited from serving half of their sentence under house arrest; in Kazakhstan, the responsibility of officials - up to dismissal - for the commission of corruption crimes by their subordinates was established.

It was the real drama this year in Ukraine around the current norms on criminal liability for violations in declarations: in October, the Constitutional Court recognized these provisions of the Criminal Code, as well as the powers of the NACP to check declarations unconstitutional, as a result, the work of the department for conducting investigations was paralyzed, including against a number of high-ranking officials and judges of the Constitutional Court, and access to the electronic register of declarations of officials was also temporarily closed. In December, the criminal responsibility and powers of the NACP were restored, but the anti-corruption body was dissatisfied with the proposed version of the article of the Criminal Code, believing the punishment in the form of restriction of freedom to be too "lenient" [12]. 
Some countries also took measures aimed at improving the ongoing investigations of corruption crimes: in Ukraine, an electronic system was launched in a test mode that allows monitoring the progress of criminal investigations; in South Korea, a special body was created to investigate cases of corruption among high-ranking officials; in Uzbekistan - an anti-corruption agency endowed, among other things, with the functions of conducting administrative investigations in cases of corruption offenses [13].

Some countries, such as Singapore, Portugal, Sweden and Hong Kong, have made some progress in this area. In these countries, the level of corruption is extremely low due to the use of a set of measures:

1. Creation of a system of internal control, in which the internal mechanisms and incentives for fair functioning work in the state body itself.

2. Successful functioning of external control bodies: independent courts, free work of the media and others.

3. Democratic system of independent elections.

4. Measures of a general nature, such as information awareness of citizens, openness of actions of government agencies, etc. [14].

Besides, the European Anti-Fraud Office announced plans to establish an independent European Union international prosecutor's office to investigate, prosecute and adjudicate criminal cases affecting EU financial interests.

The COVID-19 pandemic that broke out in 2020 affected many areas of life, including the anti-corruption sphere: against the background of increased specific risks of corruption, international organizations (GRECO, UN, OECD and others) sought to formulate recommendations to minimize them, and countries - took measures to combat corruption.

The pandemic also affected international cooperation: although some events, for example, the first meeting of the G20 Anti-Corruption Working Group, managed to take place before the introduction of quarantine measures, many meetings were postponed indefinitely or moved to the online format.

For example, in October - for the first time in the history of the G20 - a meeting of heads of state bodies responsible for coordinating national anti-corruption policies took place, during which, among other things, the initiative of Saudi Arabia to create a Global Operational Network of Law Enforcement Agencies against Corruption was supported.

In December, the 19th International Anti-Corruption Conference was held, in which more than 7,000 listeners from 135 countries took part, and a round table of the BRICS countries on anti-corruption education and training was held at the Higher School of Economics.

However, quarantine did not paralyze the activities of international organizations: during the year, a lot of analytical and other materials related to anti-corruption issues were prepared.

For example, the OECD issued a guide to ensuring integrity in the public sector and a report on the implementation of anti-corruption reforms in the countries of Eastern Europe and Central Asia, the UN High-level Group on Financial Accountability, Transparency and Integrity created in March 2020- an interim report on its activities and a number of background papers, the World Bank - a report on the use of blockchain technology to combat corruption in public procurement, TRACE International - a global report on transnational bribery enforcement practices, and a paper on traditional Chinese practice of Guangxi.

State bodies of individual countries also presented their reports, for example, the UK Public Sphere Standards Committee and the French Anti-Corruption Agency.

A number of anti-corruption ratings have been updated, such as the Corruption Perceptions Index, the Rule of Law Index, and the Financial Secrecy Rating. 
In addition, the International Consortium of Investigative Journalists published the results of its investigation of the links of the largest financial institutions to money laundering, fraud and other financial crimes, based on the FinCEN data leakage.

This year's Corruption Perceptions Index (CPI) paints a grim picture of the level of corruption around the world. [15] While most countries have not done well in the fight against corruption or have made minimal progress in nearly a decade, more than two-thirds of them scored less than 50 points. Our analysis shows that corruption not only threatens the global fight against COVID-19, but also contributes to an ongoing crisis of democracy. [16]

Due to the global pandemic COVID-19 and its devastating consequences, 2020 turned out to be one of the hardest in recent history. The health and economic impact of COVID19 at the level of individuals and communities around the world has been catastrophic. More than 90 million people fell ill, almost 2 million died. As the turbulent past year has shown, COVID-19 has triggered not only a health and economic crisis, but also a wave of corruption, the detrimental effects of which have prevented the fair and equitable provision of global assistance and led to the death of many people.

Reports of corruption during the COVID-19 pandemic have received global resonance. Corruption in healthcare takes many forms, from bribery and embezzlement to overpricing and favoritism. However, if during the crisis the lessons would not have be learned from the previous experience, the losses could be even greater.

\section{Deductions}

Existing research shows that corruption negatively affects the availability of high-quality health care for people, and our analysis also demonstrates that, even with economic development, higher levels of corruption are accompanied by lower health coverage and higher rates of infant and maternal mortality, as well as mortality from cancer, diabetes, respiratory and cardiovascular diseases.

Corrupt crimes are undoubtedly one of the main obstacles to the achievement of the United Nations Sustainable Development Goals (SDGs), and the COVID-19 pandemic further complicates the achievement of these goals. The long-term effects of corruption on health systems remind us that corruption often exacerbates the impact of a crisis. Corruption is involved in all measures to combat COVID-19, from bribes to test for COVID-19, the provision of treatment and other health services to government procurement of medical supplies and the impact on overall emergency preparedness. Our analysis shows that corruption distracts funds from much-needed investments in health care, leaving communities without doctors, equipment, medicines and, in some cases, clinics and hospitals. Besides, the lack of transparency in public spending increases the risk of corruption and ineffective crisis response [17].

Budget transparency, especially when responding to such emergencies as the COVID19 pandemic, where speed and efficiency are important, can be difficult to achieve in times of crisis. However, transparency is key to the proper use of public resources and the outreach to intended beneficiaries. For this reason, it is necessary to develop reliable and transparent procedures for the allocation of budget provisions and the conclusion of government contracts, as well as implement audit procedures before the onset of a crisis.

Finally, the study found that corruption continues to undermine democratic foundations even during the COVID-19 pandemic. Countries with higher levels of corruption are more likely to experience violations of democratic rule of law and the principles of rule of law during the COVID-19 crisis. 


\section{Conclusion}

In conclusion, it should be noted that Russia must maintain the full sovereignty of the state, as one of the few leading powers. To gain full economic sovereignty, it is necessary to neutralize the corruption component in order to ensure the economic security of the Russian Federation. This, in turn, will contribute to the development of the state, society and ensure a decent standard of living for the citizens of our country.

It has been established that the causes of corruption in public administration can be classified depending on a variety of factors. For example, according to the sources of occurrence, the causes of corruption risks can be considered as external and internal. At the same time, the group of external causes may include legal, political, economic, social ones, etc., and they are necessarily associated with the general conditions for the functioning of the public administration system. Internal reasons, in turn, will be determined by organizational and legal activities within a state institution, although they may also contain an economic and social component.

\section{References}

1. S. Rose-Ackerman, The Economics of Corruption. From Plan to Market: Patterns of Transition. Policy Research Working Paper No. 1564 (World Bank, 2006)

2. A. Ades, R. Di Telia, Political Corruption (2020)

3. A. Ades, R. Di Telia, Rents, Competition, and Corruption. American Economic Review 89(4), 982-993 (1999)

4. M. De Melo, A.G. Cevdet Denizer, Stoyan Tenev, World Bank Policy Research Working Paper 1866 (1997)

5. E.V. Romashin,a State power and local government 7 (2016)

6. Federal Law of December 25, 2008 No. 273-FZ (as amended on October 30, 2018)

7. A.A. Sudakov, Russian judge 1, 17 (2017)

8. Corruption in Russia, http://ruxpert.ru/

9. TASS. In Russia, $16 \%$ of economic crimes are committed by business, https://tass.ru/ekonomika/8554543

10. Realnoe Vremya, https://realnoevremya.ru/news/205464-uscherb-ot-korrupcii-v-2020godu-sostavil-63-mlrd-rubley

11. All-Russian public organization "Public Commission for Combating Corruption", http://www.komis-korrup.ru/index.html.

12. https://anticor.hse.ru/main/news_page/antikorruptsionnye_itogi_2020_goda

13. Interregional public organization "Committee for the fight against corruption", http://com-cor.ru/

14. M.V. Shedyy, Vestnik of the University 19, 260 (2018)

15. Transparency International: CORRUPTION PERCEPTIONS INDEX (2019) https://www.transparency.org/cpi2019?/news/feature/cpi-2019

16. All-Russian public organization "Public Commission for the Fight against Corruption", http://www.komis-korrup.ru/index.html.

17. Corruption in Russia, http://ruxpert.ru/ 